TINJAUAN PUSTAKA

\title{
Anestesi pada Pediatrik dengan Kelainan Porfiria Herediter
}

\author{
Agus Rukmana*, Johan Arifin* \\ *Bagian Anestesiologi dan Terapi Intensif FK Undip/ RSUP Dr. Kariadi, Semarang
}

\section{ABSTRACT}

The porphyrins play a critical role in biology, being involved in a wide range of reactions related to oxygen utilization, transport, storage or formation. The synthetic pathway involved in the production of the porphyrins is complex and is key wordgoverned by a sequence of enzymes. A defect in any of these enzymes results in accumulation of the preceding intermediaries and produces one form or another of the diseases known as the porphyrias.

Four hereditary types of porphyria are now classified as acute porphyrias. Enzymatic defects result in accumulation of porphyrin precursors (usually ALA and PGB). The quantity of these precursors may be normal or slightly increased in latent periods but increase to toxic levels during a porphyric crisis. Iatrogenic induction of ALA synthetase by administration of certain triggers (classically barbiturates) is only one of several factors which contribute to porphyric crisis. Signs and symptoms of acute porphyric attack consist primarily of neurologic dysfunction, which occurs secondary to neurotoxicity of ALA or diminished intraneuronal heme levels.

\begin{abstract}
Any patient in whom porphyria is suspected requires a careful history, including a detailed family history, and thorough physical examination, including a careful neurological assessment, paying particular attention to the presence or absence of peripheral neuropathy and autonomic instability.
\end{abstract}

Appropriate anesthetic management of porphyria requires knowledge of the type of porphyria (acute vs non -acute), assessment of latent versus active (crisis) phase, awareness of clinical features of porphyric attack, and knowledge of safe pharmacologic intervention disorders.

Preoperative preparation in a patient with porphyric include the careful assessment of fluid balance and electrolyte status. Technic anesthetic can be regional or general anesthesia depend on patient condition. Premedication, technic anesthetic, induction, maintenance and post anesthesia must be considerable safe for the patient.

Key word : porphyria, hereditary of porphyria, anesthetic management

\begin{abstract}
ABSTRAK
Pasien dengan porfiria terjadi perubahan biologi yang penting diketahui berkaitan dengan penggunaan oksigen, transportasi, bentuk dan penyimpanan. Jalur sintetis yang terlibat dalam produksi porfirin kompleks dan melibatkan banyak enzim. Defek pada salah satu hasil enzim dalam akumulasi perantara sebelumnya menghasilkan satu bentuk atau bentuk lain dari penyakit yang dikenal sebagai porfiria.

Empat jenis dari porfiria herediter diklasifikasikan sebagai porfiria akut. Cacat enzimatik mengakibatkan akumulasi prekursor porfirin (biasanya ALA dan PGB). Jumlah
\end{abstract}


prekursor ini mungkin normal atau sedikit meningkat pada periode laten tetapi peningkatan selama krisis porphyric dapat menyebabkan bahaya pada tubuh. Induksi iatrogenik dari sintetase ALA dengan pemberian pemicu tertentu (barbiturat) hanya salah satu dari beberapa faktor yang berkontribusi terhadap krisis porphyric. Tanda dan gejala serangan porphyric akut terutama terdiri dari disfungsi neurologis, yang terjadi sekunder pada neurotoksisitas ALA atau berkurang tingkat heme intraneuronal.

Setiap pasien yang dicurigai porfiria membutuhkan anamnesa yang teliti mengenai riwayat penyakit, termasuk riwayat keluarga dan pemeriksaan fisik secara menyeluruh, termasuk penilaian neurologis. Titk berat perhatian khusus pada ada atau tidak adanya neuropati perifer dan ketidakstabilan otonom.

Manajemen anestesi pada porfiria membutuhkan pengetahuan tentang jenis porfiria (akut vs non-akut), penilaian laten dibandingkan aktif (fase krisis), kesadaran gambaran klinis serangan porphyric, dan pengetahuan tentang intervensi farmakologis yang aman.

Persiapan pra operasi pada pasien dengan porphyric meliputi penilaian keseimbangan cairan elektrolit dan status. Teknik anestesi dapat dilakukan regional ataupun anestesi umum tergantung pada kondisi pasien. Premedikasi, teknik anestesi, induksi, pemeliharaan dan pasca anestesi harus yang cukup aman bagi pasien.

Kata kunci: porfiria, turun-temurun dari porfiria, manajemen anestesi

\section{PENDAHULUAN}

Porfiria memberikan tantangan yang khusus bagi anestesi, termasuk didalamnya adalah penilaian preoperatif pasien dengan keluhan abdomen akut, manajemen intraoperatif, manajemen krisis respirasi dan kardiovaskular pada porphyric akut. Untuk menjawab tantangan, pemahaman menyeluruh mengenai porfiria sangat penting.

Acute Intermitten Porphyria (AIP), Hereditary Copro Porphyria (HCP), dan Variegate Porphyria (VP) menunjukkan transmisi dominan autosomal dengan ekspresi variabel. Frekuensi AIP diperkirakan 1/20, 000 di Eropa, dengan tertinggi 1/10, 000 di Northern Swedia. porfiria kekurangan ALA dehidratase, juga dikenal sebagai plumboporphyria (PLP), memiliki pola dominan autosomal.

Frekuensi HCP juga sulit untuk memperkirakan sejak lebih dari setengah dari individu yang terkena tidak menunjukkan gejala (variabel ekspresi) dan jumlah kasus yang dilaporkan cukup kecil. VP sangat umum pada populasi kelompok tertentu, seperti Afrika Selatan kulit putih, di mana prevalensi diperkirakan 1/250-500. ${ }^{1}$

Beberapa tahun terakhir telah ada kajian komprehensif dari isu yang terkait dengan porfiria yang menjadi perhatian anestesi yaitu keadaan klinis, patofisiologi, pemantauan, dan farmakologi yang relevan. Tinjauan signifikan terakhir dari 
subjek ini memberikan perspektif farmakologis baru, tetapi banyak informasi yang relevan dengan anestesi tidak ditangani, seperti metode baru deteksi dan peran Arginate hematin dan heme dalam pengobatan. Analisis DNA pasien diduga porphyric cukup menjanjikan sebagai diagnosis pasti dari penyakit dengan demikian memberikan kesempatan untuk pengelolaan yang lebih aman. Manajemen anestesi yang aman untuk porfiria sangat diperlukan sama halnya dengan pemahaman terapi farmakologisnya. Hal Ini menuntut pemahaman menyeluruh pada banyak aspek lain dari penyakit ini. ${ }^{1}$

\section{Patofisiologi}

Porfiria adalah kelompok penyakit cacat enzimatik yang diwariskan atau diperoleh dari biosintesis heme. Setiap jenis porfiria memiliki pola karakteristik kelebihan dan akumulasi prekursor heme berdasarkan lokasi dari disfungsional enzim dalam sintetik jalur heme (Gambar 1). ${ }^{2}$

Langkah dalam membatasi sintesis heme adalah kondensasi suksinil CoA dan glisin untuk membentuk deltaamino acid levulinic (ALA) yang dikatalisasi oleh enzim ALA mitokondria sintetase. Aktivitas basal sintetase ALA secara substansial lebih rendah daripada enzim berikutnya dalam jalur sintetis sehingga perubahan ALA sintetase adalah untuk mengontrol laju sintesis heme. Heme, produk akhir dari jalur sintetik, merupakan regulasi umpan balik negatif pada aktivitas ALA sintetase. Defisit spesifik enzim dalam setiap jenis porfiria pada blok parsial dalam biosintesis heme menurunkan tingkat heme intramitochondrial. Penurunan umpan balik negatif dari heme berkontribusi pada peningkatan aktivitas sintetase ALA yang berkarakteristik porfiria. $^{2}$

Manifestasi penyakit disebabkan sintetase ALA meningkat, peningkatan akumulasi porfirin dalam jaringan, atau penurunan produksi heme. Peningkatan ALA hasil aktivitas sintetase dalam kadar prekursor heme proksimal menuju tempat enzim tertentu yang berkurang. Prekursor ini tidak berwarna dan nonfluorescent porphyrinogens. Oksidasi ireversibel dari porphyrinogens menyebabkan pembentukan

porfirin, yang tidak memiliki fungsi fisiologis yang dikenal, tetapi merupakan oksidan yang reaktif. Akumulasi porfirin dalam lapisan kulit epidermis tersebut menyebabkan photosensitivitas pada kulit.

Porfiria akut sering menyebabkan neuropati berat, yang mendasari penurunan multisistem. Perubahan ganglia otonom, anterior horn dari sumsum tulang belakang, saraf perifer, inti batang otak, akson cerebellar, sel Schwann dan selubung myelin telah terbuktikan. Kerusakan saraf dan degenerasi aksonal mungkin lesi patologis utama, yang kemudian berlanjut perubahan aksonal yang 
mengarah ke demielinasi sekunder.

\section{Klasifikasi dan Insiden}

Porfiria diklasifikasikan berdasarkan tiga karakteristik: ${ }^{3}$

1. Produksi porfirin yang abnormal (hepatic vs erythropoietic)

\section{Akut atau nonacute}

\section{Pola kekurangan enzim dalam produksi heme.}

Heme adalah komponen dari sistem sitokrom mikrosomal dan mitokondria dan disintesis dalam semua sel. Dua situs kuantitatif utama sintesis heme yang erythropoeitic dan sel-sel hati di mana heme dimasukkan ke dalam hemoglobin dan hati sitokrom. Porfiria Erythropoeitic menyebabkan sensitivitas kulit ekstrim tetapi kurangnya neurologis keterlibatan dan tidak terkait dengan krisis endapan obat. ${ }^{4}$

Porphyria cutanea tarda (PCT) adalah porfiria hati tanpa sisa gejala neurologis.

PCT biasanya dikaitkan dengan penyakit hati tapi krisis neurologis tidak akut. Porfiria hati juga berhubungan dengan nyeri perut, neuropati perifer, dan perubahan status mental, dengan krisis sering dipicu oleh obat. Barbiturat adalah paling sering sebagai pemicu. Ada sedikit perbedaan dalam sindrom neurologis. Selama serangan diantara empat porfiria, porfiria hati akut, HCP dan VP mempunyai manifestasi photosensitiv pada kulit dan kerapuhan kulit yang ekstrim,sedangkan AIP tidak. ${ }^{4}$
AIP dikaitkan dengan prognosis yang relatif baik. Gejala terjadi kurang dari sepertiga pasien yang rentan secara genetik tetapi jarang sebelum pubertas. Serangan Akut berhubungan dengan risiko yang signifikan dari kematian, terutama jika diagnosis tertunda dan adanya gangguan neurologis. Meskipun autosomal dominan, ekspresi klinis lebih umum pada wanita. Kebanyakan pasien dengan HCP tidak menunjukkan gejala dan onset klinis mungkin terkait dengan intercurrent penyakit hati. Gejala klinis terjadi antara usia 7 dan 75 tahun dan prognosis umumnya baik.

VP memiliki prognosis sebagus porfiria intermiten akut. Efek sistemik lebih sering terjadi pada wanita, sedangkan manifestasi kulit lebih sering terjadi pada laki-laki. Pengobatan dilakukan dengan menurunkan tingkat heme, sehingga mengurangi umpan balik negatif dan dengan demikian meningkatkan aktivitas ALA sintetase. Obat yang biasa digunakan banyak memicu krisis porphyric yang berakibat menurunnya heme. Barbiturat menginduksi sistem sitokrom P450, hal ini menggabungkan heme lebih ke yang sitokrom baru, sehingga mengurangi tingkat heme. Kontrasepsi oral menyebabkan kerusakan heme dalam sitokrom dan membutuhkan heme baru untuk dimasukkan ke sitokrom. Griseofulvin mengubah heme menjadi N-alkohol derivatif, yang selanjutnya menghambat hemesintesis.

Beberapa hormon steroid endogen yang diduga memicu porfiria dengan 
meningkatkan sintesis enzim sintetase ALA baru. Faktor-faktor yang dapat menurunkan aktivitas sintetase termasuk asupan tinggi karbohidrat (glukosa) , propranolol, dan umpan balik negatif dari heme. Propranolol digunakan selama serangan akut untuk mengontrol porphyric hipertensi dan takikardia. Obat ini meningkatkan sintesis heme in vitro, yang diberikannya merupakan usaha menghambat pada aktivitas sintetase ALA melalui umpan balik negatif. Porfiria akut berhubungan dengan defisit enzim turun-temurun.

Kehamilan dapat memperburuk atau memprovokasi serangan akut. Menghindari kehamilan yang direncanakan sampai periode laten satu tahun telah berlalu sangat dianjurkan. Tingkat mortalitas dari Serangan akut di antara pasien hamil telah dilaporkan setinggi $42 \%$.

\section{Gambaran klinis serangan akut ${ }^{5}$}

Serangan akut hanya terjadi pada empat jenis porfiria: AIP, HCP, VP, dan PLP. Tanda-tanda dan gejala krisis porphyric akut yang sering terjadi adalah: sakit perut yang parah, muntah, gelisah, kebingungan, ketidakstabilan otonom yang bermanifestasi hipertensi dan takikardi, dehidrasi, gangguan elektrolit seperti hiponatremia, hipokalemia, dan hypocalcemia. AIP, HCP, dan VP mungkin secara klinis dibedakan selama serangan akut. Pusat untuk masingmasing disfungsi neurologis, dengan penurunan yang signifikan baik simpatis dan parasimpatis sistem saraf terjadi selama serangan akut. Selama remisi fungsi membaik, namun disfungsi parasimpatis dapat bertahan. Takikardia seringkali merupakan indikator perkembangan tingkatan penyakit. Terjadi kenaikan beban jantung, kondisi pasien umumnya memburuk dan dengan perbaikan takikardia, klinis biasanya membaik. Sebagian besar gejala klinis mereda seiring perjalanan waktu dari krisis akut, namun sisa paresis dapat bertahan selama bertahun-tahun dalam ketiadaan serangan lanjut . paresis tidak memiliki implikasi khusus untuk penggunaan relaksan neuromuskuler. Pemulihan fungsi mental seringkali tertinggal dibanding pemulihan fisik, dan beberapa pasien dilaporkan mengalami kecemasan dan ketidakstabilan emosional. Kelainan elektrolit terjadi sekunder karena dehidrasi, muntah, dan diare, dan mungkin terjadi hiponatremia dan hypochloremia. Stein et al melakukan penelitian radioisotop untuk mengukur volume darah dalam sembilan pasien AIP. Semua memiliki volume darah yang rendah, mulai dari $67 \%$ sampai $97 \%$ dari normal, meskipun elektrolit normal pada beberapa pasien. Sindrom sekresi anti-diuretik hormon (SIADH) dapat dijelaskan dalam porfiria akut, mungkin karena keterlibatan hipotalamus dan hiponatremia.

Diagnosis laboratorium krisis porphyric dapat dilakukan analisis feces tetapi sebagian sering melibatkan kuantifikasi porfirin urin dan prekursor porphyrinogen. Pemeriksaan ini semakin meningkat selama serangan, namun 
dapat kembali ke normal selama remisi. Salah satu teknik yang dikenal untuk analisis keterkaitan gen dengan pendekatan baru untuk diagnosis porfiria intermiten akut bergantung pada urutan cDNA langsung. Pemeriksaan ini tidak tergantung pada urine melainkan pada penanda polimorfik dalam gen deaminase porphobilingen. Hal ini memungkinkan deteksi lebih awal dari dokter. deteksi dini dan akurat pada penyakit pasien dengan risiko tinggi memberikan manfaat yang jelas untuk manajemen anestesi yang lebih aman.

\section{Evaluasi preoperatif}

Gejala-gejala berikut harus meningkatkan kecurigaan porfiria pada pasien dengan sakit perut akut: perubahan status mental (kebingungan, histeria), neuropati perifer (motorik> sensorik), urin berwarna gelap (merah ungu), dan keluarga yang diketahui sejarah porfiria. Perhatian khusus adalah pada masa nifas dengan nyeri perut akut. Lebih dari 50\% wanita hamil yang memiliki porfiria akan mengalami krisis selama kehamilan atau masa nifas, mungkin karena induksi ALA sythetase oleh perubahan hormonal kehamilan. ${ }^{6}$ Jika pasien dengan abdomen akut, hamil atau tidak, tidak memiliki sugestif gejala porfiria, obat anestesi dan terapi tidak boleh diubah.

Dalam penatalaksanaan porfiria akut, mungkin situasi yang paling sulit adalah pada serangan akut bersamaan dengan proses penyakit yang mengharuskan intervensi bedah, yaitu infeksi, demam, dan anorexia, contohnya pada apendisitis akut merangsang ALA sintetase dan mempercepat terjadinya krisis. Evaluasi neurologis harus fokus pada status mental dan neuropati perifer. Jika krisis yang akut dicurigai, perhatian terhadap disfungsi cerebral dan mata dapat memprediksi kegagalan pernapasan yang akan terjadi. Premedikasi penting, karena stres psikologis telah dilaporkan dapat menjadi serangan akut. ${ }^{7}$ Narkotika aman pada porfiria, dengan pengecualian pentazocine, suatu agonis parsial. Scopolamine dan atropin dianggap aman. Penenang nonnarcotic termasuk droperidol, promethazine, kloral hidrat, dan diphenhydramine. Pemberian antagonis H-2 dan antasida untuk pencegahan aspirasi dianjurkan. Pemberian simetidin direkomendasikan pada keadaan krisis porphiria akut untuk mencegah konsumsi heme dan menurunkan aktifitas ALA sintetase.

\section{Manajemen intraoperatif}

A. Regional anestesi ${ }^{8}$

Porfiria akut bukan merupakan kontraindikasi absolut terhadap anestesi regional tetapi memerlukan pemeriksaan neuropati perifer yang rinci pra operasi. Potensi perubahan status mental dan kerjasama pasien sangat penting. Bupivakain aman untuk anestesi regional. Sementara beberapa bukti menunjukkan bahwa lidokain dapat meningkatkan aktivitas sintetase ALA dalam sel kultur jaringan hewan, tidak ada eksaserbasi klinis dilaporkan setelah 
Gambar 1. Metabolisme Porfirin

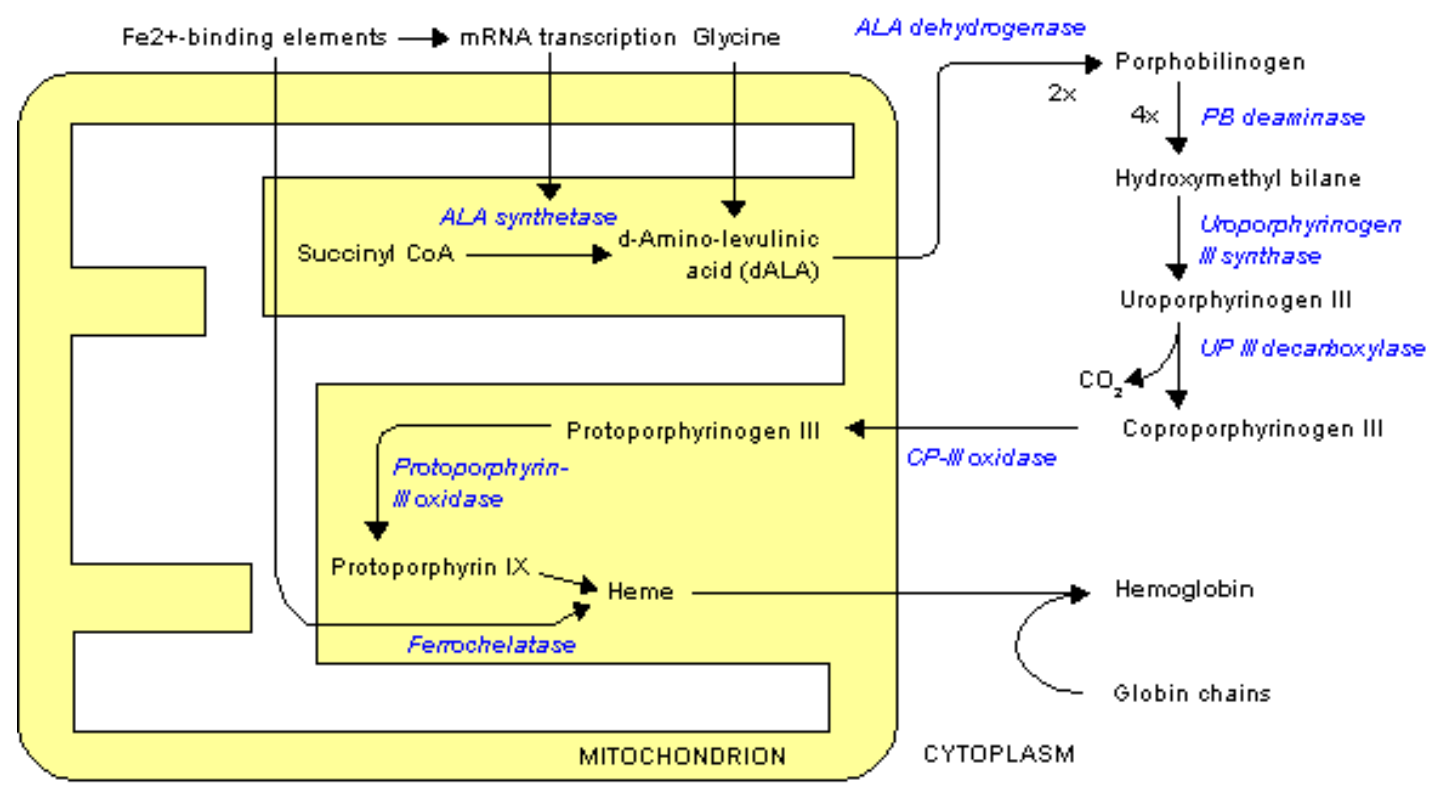

Tabel 1. Porfiria dan obat anestesi ${ }^{1}$

\begin{tabular}{|c|c|c|c|}
\hline Kelompok obat & Umumnya aman & Tidak aman & Tidak jelas \\
\hline $\begin{array}{l}\text { Obat intra vena } \\
\text { Agen inhalasi } \\
\text { Obat neuromuskular } \\
\text { Premedikasi } \\
\text { Opioids } \\
\text { Anticholinestrase } \\
\text { Local anesthetics } \\
\text { Kardiovasculer } \\
\text { Lainnya }\end{array}$ & $\begin{array}{l}\text { Midazolam } \\
\text { Lorazepam } \\
\text { Propofol } \\
\text { Nitrous oxida } \\
\text { sevoflurane } \\
\text { Succinil cholin } \\
\text { Vecuronium } \\
\text { rocuronium } \\
\text { Scopolamin } \\
\text { Atropin } \\
\text { Droperidol } \\
\text { Promethazin } \\
\text { Chloral hidrat } \\
\text { Diphenhidramin } \\
\text { Cimetidin } \\
\text { Morphine } \\
\text { Fentanyl } \\
\text { Neostigmin } \\
\text { Bupivacain } \\
\text { Procain } \\
\text { Atenolol } \\
\text { Labetolol } \\
\text { Reserpine } \\
\text { Phentolamin } \\
\text { Glukosa } \\
\text { antikonvulsan } \\
\end{array}$ & $\begin{array}{l}\text { Barbiturat } \\
\text { Etomidate } \\
\text { Chlordiazepoxid } \\
\text { Flunitrazepam } \\
\text { Nitrazepam } \\
\text { Enflurane } \\
\text { Pentazosin } \\
\text { Kontrasepsi oral } \\
\text { Griseofulvin } \\
\text { Streroid endogen }\end{array}$ & $\begin{array}{l}\text { Isoflurane } \\
\text { Halothan } \\
\text { Pancuronium } \\
\text { Atracurium } \\
\text { Sufentanil } \\
\text { Lidocain }\end{array}$ \\
\hline
\end{tabular}


pemberian ester atau amida lokal anestesi. Prokain menurunkan aktivitas sintase ALA dalam hati tikus percobaan. Anestesi regional mungkin harus dihindari dalam pengaturan krisis porphyric akut. Gangguan neuropati mungkin dalam onset cepat, mengaburkan perbedaan antara onset daerah anestesi dan neuropati porphyric progresif. Selain itu, perubahan status mental sering membuat pasien porphyric tidak kooperatif. Hipovolemia dan respon otonom labil, karakteristik krisis porphyric akut, meningkatkan risiko ketidakstabilan hemodinamik akibat blok simpatis. Namun, tidak ada penelitian khusus untuk keadaan ini, mungkin efek sekunder yang terjadi adalah sekitar masalah etika dan medicolegal lembaga anestesi regional gangguan neurologis akut sementara yang terjadi.

\section{B. Induksi anestesi}

Thiopental merupakan sebagian besar obat yang dapat menyebabkan serangan, tetapi krisis porphyric alami membuat interpretasi menjadi sulit karena terjadinya multifaktorial. Gangguan hormon, dehidrasi, infeksi, demam, dan steroid endogonous dapat menginduksi ALA sintetase pada hampir semua obat yang diberikan kepada pasien yang memasuki krisis porphyric berimplikasi bahwa obat sebagai "pemicu". Bahkan Pemicu dikenal tidak dapat menyebabkan serangan. Misalnya, Ward, 36 kasus induksi dengan barbiturat anestesi umum pada pasien dengan Porfirio, tidak ada yang mengalami krisis porphyric pascaoperasi. Dalam studi lain, thiopental diberikan kepada 27 pasien dengan porfiria akut tetapi tidak terjadi keadaan krisis. Tak satu pun dari pasien yang berkembang menjadi serangan pasca operasi. Dari 10 pasien yang berada dalam krisis yang akut sebelum induksi anestesi dengan thiopental, tujuh pasien mengalami gejala porphyric yang memburuk.

Pemberian obat porphyrinogenic tidak, dengan sendirinya, menentukan apakah serangan akan terjadi. Pemberian obat tersebut mungkin hanya satu faktor yang dapat memicu krisis. Oleh karena itu, meskipun thiopental tidak akan selalu berkembang menjadi krisis, barbiturat merupakan kontraindikasi pada pasien porphyric. ${ }^{9}$

Benzodiazepines bervariasi dalam potensi menjadi porphyrinogenic. Diazepam sebagai "pemicu" karena memiliki chlordiazepoxide, flunitrazepam dan nitrazepam. Namun, diazepam telah digunakan dengan aman selama krisis porphyric. Midazolam telah digunakan dengan aman untuk induksi anestesi pada pasien dengan VP, sebagaimana pada lorazepam. ${ }^{9}$

Etomidate porphyrinogenic pada hewan. Satu kasus telah dilaporkan untuk induksi pada pasien porfiria laten dengan keadaanklinis baik, tapi setidaknya salah satu krisis porphyric manusia telah dilaporkan setelah penggunaannya. Ketamin juga diduga terlibat sebagai pemicu krisis porphyric. Penyelidikan 
Laboratorium hasil kultur jaringan, seperti ketamin tampaknya porphyrinogenic pada konsentrasi yang lebih tinggi, tetapi tidak pada tingkat klinis. Banyak yang menganggap ketamin aman pada porfiria. Propofol sebagai obat untuk induksi anestesi merupakan pilihan. Banyak pasien porphyric yang menerima propofol tanpa bukti klinis Krisis akut, ALA sintetase tidak diinduksi pada hewan coba. Uji klinis dari 13 pasien VP tidak menunjukkan bukti porphyrinogenicity saat propofol digunakan untuk induksi anestesi. Namun, seperti ditunjukkan oleh Harrison et al peningkatan ini terjadi setelah anestesi ketiga berturutturut dan tidak disertai dengan gejala apapun. Propofol dianggap "mungkin aman" meski pengawasan hati-hati untuk porphyrinogenesis setelah anestesi sangat dianjurkan. ${ }^{10}$

\section{Pemeliharaan anestesi}

Anestesi volatil umumnya aman pada pasien porphyric. Laporan dari kemungkinan asosiasi halotan dengan krisis bertentangan baik eksperimental dan pengalaman klinis. Isoflurane atau enfluran memperburuk krisis porphyric pada manusia. Namun, enflurane telah diklasifikasikan sebagai berbasis porphyrinogenic data pada hewan. Nitrous oxide dan opioid dianggap aman. Relaksan otot dilaporkan aman termasuk vecuronium dan atracurium. Sangat menarik untuk dicatat bahwa beberapa steroid dianggap tidak aman untuk porfiria. Vecuronium dan berbagi pankuronium struktur steroid, tetapi hanya yang terakhir telah dicurigai tidak aman berdasarkan data yang diperoleh dari hewan. Takahashi $\mathrm{S}$ et.all melaporkan amannya penggunaan sevoflurane sebagai agen inhalasi pada induksi cepat pada pasien dengan porphiria akut. ${ }^{11}$

\section{Manajemen Pascaoperasi}

Pemantauan terjadinya potensi krisis porphyria harus dilanjutkan sampai lima hari, karena dapat terjadi onset lambat. Terjadinya krisis dapat ditandai oleh salah satu tanda-tanda neurologis atau stimulasi sistem saraf otonom. Pada pasien tersebut, monitoring kardiovaskular yang memadai meliputi elektrokardiografi, serta kateter arteri pulmonalis, untuk mengevaluasi fungsi jantung dan bantuan dalam diagnosis dan pengobatan gagal jantung.

Pemantauan kardiovaskular dalam kejadian serangan akut harus dilanjutkan pasca operasi - sejauh mungkin, bergantung pada keadaan klinis pasien. Angka kejadian gagal jantung pasca operasi setelah serangan porfiria akut belum diketahui. Penggunaan pemantauan invasif untuk status volume harus pula dipandu oleh durasi, dan jenis operasi dan kehilangan darah serta status klinis pasien pasca operasi. Status neurologis harus dinilai sesering mungkin pasca operasi. Jika terapi antiemetik diperlukan, metoclopramide sebaiknya dihindari, namun promethazine, droperidol, atau chlorpramazine dapat diterima. ${ }^{12}$ 


\section{Penatalaksanaan krisis akut}

Manajemen krisis porfiria akut melibatkan upaya khusus untuk membalikkan faktor yang meningkatkan aktivitas ALA sintetase, menghentikan obat yang memicu, pengobatan gejala dengan obat yang tepat, dan pemantauan pasien yang tepat. Penatalaksanaan utamanya diarahkan pada membalikkan proses penyakit meliputi hidrasi, pemantauan elektrolit, pemberian glukosa $(20 \mathrm{~g} / \mathrm{hr})$, propranolol (yang dapat menurunkan aktivitas enzim serta sebagai kontrol takikardia), pengobatan infeksi yang mendasari dan heme - yang secara langsung meningkatkan umpan balik negatif ke ALA sintase. ${ }^{3}$

Hematin, sediaan yang paling sering digunakan dalam pengobatan porfiria, merupakan standar terapi, meskipun mungkin bukan yang terbaik. Hematin dapat menghasilkan perbaikan klinis yang dramatis, dengan penurunan bermakna amino-asam levulinat urin dan ekskresi prophobilinogen.

Meski demikian, efek samping yang terkait dengan hematin cukup bermakna, meliputi gagal ginjal, thrombophlebitis, dan koagulopati terkait dosis. Efek samping negatif sebagian besar terjadi karena instabilitas dari senyawa dalam infus tersebut. Masa simpan hematin hanya sekitar tiga bulan. ${ }^{3}$

Masalah-masalah dan ketidakstabilan ini telah menyebabkan pengenalan senyawa heme lain, Heme Arginate. Heme Arginate lebih stabil dalam larutan, memiliki masa simpan sekitar dua tahun, dan tidak memiliki efek yang tidak diinginkan dari hematin.

Respon terhadap terapi heme biasanya terjadi dalam waktu 2-4 hari setelah dimulainya terapi. Hematin menekan sintesis heme endogen dan menurun secara signifikan ekskresi ALA dan PBG. Namun demikian sediaan ini hanya tersedia secara komersial di Amerika Serikat adalah Panhematin (Abbott Laboratorium, Chicago, IL) dengan dosis mg / kg 3-4 hari /. Sebagai tambahan, obat ini adalah juga merupakan obat pertama yang disetujui melalui Orphan Drug Act.

Penundaan penggunaan hematin hingga 48 jam direkomendasikan oleh beberapa pihak, terutama pada kasus refrakter atau progresif cepat. Namun, informasi terbaru menunjukkan bahwa pemberian heme Arginate dini akan memperpendek masa rawat inap dan meningkatkan hasil. Meski demikian, hingga saat ini, heme Arginate, bentuk komponen yang paling stabil, belum memiliki persetujuan FDA dan tidak tersedia kecuali untuk tujuan penelitian di Amerika Amerika. Uji klinis dijadwalkan untuk mulai di University of Texas Medical Branch di Galveston dalam waktu dekat. Simetidin mungkin memiliki peran dalam pengobatan porfiria intermiten akut dengan menghambat aktivitas heme oksidase, menurunkan konsumsi heme, dan penghambat ALA sintetase melalui mekanisme umpan balik negatif. Mekanisme ini memunculkan anggapan bahwa cimetidine mungkin berguna 
sebagai agen profilaksis, menstabilkan dan memperpanjang periode remisi. Penelitian pada hewan percobaan menunjukkan yang positif, namun pada manusia hasil penelitian belum terbukti. Sementara cimetidine tidak memperburuk perjalanan klinis dan dapat digunakan secara aman sebagai antagonis $\mathrm{H} 2$ pada pasien dengan AIP, tidak muncul untuk menjadi efektif terapi profilaksis.

Nyeri yang terkait dengan serangan akut mungkin memerlukan terapi opioid. Mual dan muntah sebaiknya ditangani dengan promazine, klorpromazin, atau prochloroperazine, bukan dengan metaclopramide, yang memiliki efek porphyrinogenic. Jika gejala bulbar muncul, pengawasan seksama akan adanya gagal nafas harus dilakukan. Analisa gas darah arteri dan pengukuran FVC serial merupakan pemeriksaan penunjang lain penting. Pada pasien dengan riwayat penyakit arteri koroner , takikardia dan hipertensi yang khas terjadi pada krisis akut akan meningkatkan kebutuhan oksigen miokard dan harus dihindari.

Mortalitas akibat krisis porfiria adalah sekitar 10\% dengan rejimen pengobatan saat ini dan terutama karena dua faktor: proses infeksi yang mendasari dan kegagalan pernapasan sekunder dari depresi respiratory drive syaraf pusat atau kelumpuhan otot pernapasan. Henti jantung telah dilaporkan pada pasien dengan quadriplegia flaksid, koma, dan gejala bulbar. Kehadiran disritmia yang parah dapat mendahului serangan jantung refrakter. ${ }^{12}$

\section{Penelitian Lebih Lanjut}

Diperlukan studi klinis yang lebih besar pada penggunaan ketamin, proprofol, etomidate, dan volatile anestesi. Hanya beberapa laporan klinis yang menyebutkan keamanan dari anestesi. Pemeriksaan laboratorium atau klinis dari penggunaan atracurium atau vecuronium yang telah diteliti pada pasien dengan porfiria dan tidak terjadinya perubahan hemodinamik signifikan dengan obat ini membuat penggunaanya dalam kelompok pasien porfiria masih diterima.

\section{Ringkasan}

Empat jenis porfiria herediter sekarang diklasifikasikan sebagai porfiria akut. Terjadi cacat enzimatik mengakibatkan akumulasi prekursor porfirin (biasanya ALA dan PGB). Jumlah prekursor mungkin normal atau sedikit meningkat pada periode laten tetapi meningkathingga kadar toksik selama krisis porfiria. Induksi ALA sintase iatrogenik karena pemberian pemicu tertentu (klasik barbiturat) hanya salah satu dari beberapa faktor yang berkontribusi terhadap krisis porfiria. Tanda dan gejala serangan porfiria akut terutama terdiri dari disfungsi neurologis, yang terjadi sekunder akibat neurotoksisitas ALA atau kadar heme intraneuronal berkurang.

Manajemen anestesi porfiria yang tepat membutuhkan pengetahuan tentang jenis porfiria (akut vs non-akut), penilaian 
fase laten dibandingkan aktif (krisis), pengetahuan mengenai gambaran klinis serangan porfiria, dan pengetahuan akan intervensi farmakologis yang aman

\section{DAFTAR PUSTAKA}

1. Harrision GG, Meissner PN, Hift RJ. Anaesthesia for the porphyric patient. Anaesthesia 2003;48:417-21

2. Elder GH, Path FRC. Enzymatic defects in porphyria: an overview. Semin Liver Dis 2002;2:87-99

3. Moore MR, Disler I'B. Drug induction of the acute porphyrias. Adv Drug React AC Pois Rev 2003;2:149-89

4. Moore MR, McCall KEL, Remington C, Goldberg A. Disorder of porphyrin metabolism. New York: Plenum Medical Book Company, 2007

5. Yeung Laiwah AC, McCall KEL. Management of attacks of acute porphyria. Drugs 2007;34:604-16
6. Becker DM, Kramer S. The neurological manifestations of porphyria: a review. Medicine 2007;56:411-23

7. Bonkowsky HL, Schady W. Neurologic manifestations of acute porphyria..Semin Liver Dis 2002;2:108-24

8. L. Hines R, Marschall K. Stoelting's Anesthesia and Co-Existing Disease, 2012 ; 309

9. Mustajoki I', Heinonen J. General anesthesia in "inducible" porphyrias. Anesthesiology 2000;53:15-20

10. Meissner PN, Jarrison GG, Hift RJ. Propofol as an I.V. anaesthetic induction agent in variegate porphyria. $\mathrm{Br} \mathrm{J}$ Anaesth 2001;66:60-5

11. Takahashi S, Shiraishi Y, Yokoyama J. A case report of rapid inhalation induction with sevoflurane in a patient with porphyria. Masui 2005;54(11):1292-4.

12. Mehta M, Rath GP, Padhy UP, Marda M, Mahajan C, Dash HH. Intensive care management of patients with acute intermittent porphyria: Clinical report of four cases and review of literature. Indian $\mathrm{J}$ Crit Care Med. 2010; 14(2):88-91. 